\title{
The impact of the global economic crisis on working capital of real sector in Turkey
}

\author{
Iffet Görkey Kesimli ${ }^{1}$, Suleyman Gokhan Gunay ${ }^{2}$ \\ ${ }^{1}$ Luleburgaz Vocational School, Kirklareli University, Turkey \\ ${ }^{2}$ Faculty of Economics and Administrative Sciences, Trakya University, Turkey \\ e-mails: ifkesimli@gmail.com; suleymangokhan@gmail.com
}

\begin{abstract}
Objective of this study is to reveal the impact of the recent global economic crisis, triggered in 2007 and unveiled in 2008, on the working capital of real sector in Turkey. Since it is obvious that ratios would help in such an analysis, we have analyzed the current assets and liabilities related ratios, based on financial statements of Turkish real sector firms, quoted in the Istanbul Stock Exchange (ISE). Pre-crisis era has been compared with the crisis era, while the degrees of the affection of the real sector current assets and current liabilities have been tested through hypotheses, and two-tail-significance test has been conducted. The results of this study draw conclusions from an empirical investigation showing that the 45 ISE companies, chosen among others, have been affected on a limited basis.
\end{abstract}

JEL Classifications: F30, G01, G32

Keywords: Real sector, global economic crisis, working capital, ratio analysis.

\section{Introduction}

Contemporary companies are forced to compete in the national and also global markets under crucial rules. For sustainable profits a company has to apply a disciplinary manner, scan the rivals, and satisfy its shareholders and uncountable stakeholders. Not only companies coated in stock exchanges markets, but also the others have to apply dynamic financial management techniques and leave the old fashioned management styles. It is believed that by managing this way, a company may prosper and reach improved performance levels.

Even though the importance of efficient working capital management is well known, still there are companies on different scales not stressing working capital management. Fatih Özatay (2009) emphasizes that there are a few basic things not to be forgotten, under crises circumstances. No matter the company is public or private; there will be a problem under poor balance sheet conditions. Working capital is related to company characteristics, financial conditions and company indicators as well. Since poor performance through the end of 1990s, financial institutions applied tight credit policies in order to decrease deposit/loans ratio. In order to adapt to changing financial conditions, investors were supposed to manage more prudently their working capitals. Kargar and Blumenthal (1994) demonstrated that many investments shut-down due to bad working capital management despite healthy operations and profits (Chiou et al., 2006). In addition, minute decreases in additional working capital investment may increase the prices of shares (Strischek, 2001).

Even though working capital management, meaning the investment in current assets and comprising the management of assets which are to be liquidated in a year or less, is very crucial to companies, no efficient analyses are observed. However, net working capital affects the decisions to reach the optimum balance between the company capital and the risk. The healthy and efficient cash management and taking proper decisions considering receivables and inventory management are required. Net working capital shows the debt payment ability of the firm and is the difference between the assets and external sources to be liquidated in less than a year. 


\section{Studies about working capital}

A study on determinants of working capital management (WCM), such as conjuncture indicators, industry impact, and company cash flow, leverage, growing opportunities, company performance and size of company, has been conducted by Chiou et al. (2006). Data about 35 quarters, starting with the first quarter of 1996 and the third quarter of 2004, have been used. NLB ${ }^{1}$ and $W_{C R}^{2}$ have been applied; the results demonstrate that leverage and cash flow are affecting working capital management (2006).

Filbeck and Krueger (2005) argued that companies minimizing the fund levels on current assets are able to decrease the cost of financing or can use the excess of funds in reinvestment. These authors used CFO (Chief Finance Officer) magazine's data about yearly Company Working Capital Management Survey to make a research in the basic items of WCM. Working capital measurements of 1000 companies from 32 industry sectors, each comprising at least 8 companies, were used to calculate the mean and variance. The questions put in analysis were as follows; "is there a concentration of sector specific firms in working capital measurement?"; "does WCM performance of sector specific firms change from one year to another?" They have concluded that working capital measurements of several industry sectors seriously differ through time (Filbeck and Krueger, 2005).

\section{Global economic crisis}

In our analysis it will be proper to discuss the crisis prevailing conditions of Turkish economy. Mentioned indicators are given in Table 1 . As can be seen in the table, yearly inflation rate increased from $8.39 \%$ in the 4 th quarter of 2007 to $11.13 \%$ in the 3 rd quarter 2008. Central Bank's interest rate increased from 15.75\% to $16.25 \%$ during the same period. Due to the cash outflows, dollar/TL parity depreciated from 1.26 in the 3rd quarter 2008 to 1.67 in the 1 st quarter of 2009 . Unemployment rate increased from $10.3 \%$ to $15.8 \%$ during the same period.

The growth rate in Gross Domestic Product (GDP) dropped from $0.9 \%$ to $-14.6 \%$ in the same period. As a result of this huge drop in the GDP rate, the inflation rate dropped from $11.13 \%$ in the 3 rd quarter of 2008 to $5.27 \%$ in the 3 rd quarter of 2009 . There was a parallel shift in the interest rates of the Central Bank; the interest rate decreased from $16.75 \%$ to $7.25 \%$ during the same period. The growth rate of GDP sustained positive: it is $6 \%$ in the 4 th quarter of 2009 . As a result of these prevailing economic conditions in Turkey, it would not be wrong to argue that the impact of Global economic crisis (GEC) did not continue for long period of time.

There were short-term capital outflows in the third quarter of 2008 in emerging markets due to the GEC. As a result of these capital outflows, Turkish Lira depreciated against other currencies, economic growth diminished, and unemployment increased. GEC led to increase in the currency, liquidity and credit risks in emerging markets like Turkey. These risks also influenced real sector in Turkey.

During GEC, it is believed that every country and almost each sector and most of the companies are affected negatively. However, while causing threats in some sectors, crises also bring new opportunities to some others. Therefore, it would be meaningful to analyze companies representing the sector they are in. The crisis is not over yet. This is why it is not possible to diagnose exact effect of it. However, it is possible to understand the short term effect of the crisis. Working capital management is one of the cornerstones of business continuity and acts as a hedge against tightening credit and access to additional

\footnotetext{
1 NLB $=$ Net Liquid Balance. [(cash and the like + short term investments) - (short term liabilities + commercial notes payables + long term investments' payments due in a year)].

2 WCR $=$ Working Capital Requirements. [(receivables + inventory) - (liabilities + incurred expenditures +other liabilities)].
} 
capital. Companies which manage their working capital optimally during times of recessions come out stronger after the recession period. During times of boom cycles it is easy to forecast working capital needs and manage liquidity. The real test however comes during bust cycles as witnessed by the world during 2008 and 2009. GEC has forced many companies into cash flow problems, due to non availability of working capital, which in turn have led to shrinkage of operations, postponement of plans for capital expansion into different markets, etc.

Thus, the impact of GEC on the working capital (current assets and current liabilities) of real sector in Turkey is analyzed in this study by using ratio analyses. Similar studies are explained in the following section. Next section explains research methodology of the study. The rest sections present empirical findings and conclusion.

\section{Similar studies about the impact of economic crisis on real sector}

One of the studies including the economic crisis period between 1999 and 2001 examined the impact of financial leverage on 96 firms in four sectors of the real sector in Turkey for twelve periods (Gunay, 2002). By using t-tests and regression analysis, this study proved that the sectors with high leverage have lost more than the ones with low leverage after economic crisis. Another study, which focused on the same economic crisis in Turkey for the periods 1999 and 2002, found similar results (Dogan, 2005). Liquidity ratios, asset management ratios and profitability ratios were used in this study in order to examine the impact of economic crisis on Turkish real sector. The empirical findings of this study showed that average sales incomes of 100 manufacturing firms that are quoted in Istanbul Stock Exchange in 1997 are below their sales levels at the end of 2001.

There are also studies examining the impact of GEC on emerging markets. Yang and Young (2009) have examined the impact of GEC on South Korean economy. They have found that intensive capital outflows by foreign investors created a serious impact on this economy even though macroeconomic indicators of South Korea were very strong before the crisis. These sudden capital outflows are termed as "Systemic Sudden Stops" by Calvo, Isquierdo and Mejia (2008). Jacob and Chander (2009) also studied the impact of GEC on Indian economy. They have examined the periods between 2005 and 2009 for 192 firms in nine sectors of Indian real sector. They have found that GEC has not affected the real sector in India substantially. Countries that are dependent on commodities (e.g., South Africa) are also affected from GEC. As the economic crisis deepened at the end of 2008, platinum group of metal mining companies in South Africa were forced to lay-off about 10.000 employees, and foreign investments were also adversely affected (Te Velde, 2008). It is documented by Cali, Massa and Te Velde (2008) that foreign direct investment to countries such as Turkey declined by $40 \%$ in 2008 .

\section{Research methodology}

In order to understand the impact of the GEC on the working capital components, thirteen ratios specifically related to working capital have been used in this analysis. The list of these ratios is as follows:

1. Current Ratio (CR)

2. Liquidity Ratio (LR)

3. Cash Ratio (CAR)

4. Inventory-to-Current Assets Ratio (ICAR)

5. Short Term Receivables-to-Current Assets Ratio (STRCAR)

6. Current Assets-to-Total Assets Ratio (CATAR)

7. Short Term Liabilities-to-Total Assets Ratio (STLTAR) 
8. Short Term Liabilities-to-Total Liabilities Ratio (STLTLR)

9. Short Term Bank Loans- to- Short Term Liabilities Ratio (STBLSTLR)

10. Stock Turnover Rate (STR)

\section{Receivables Turnover Rate}

\section{Working Capital Turnover Rate}

\section{Net Working Capital Turnover Rate}

For evaluation of the listed ratios, 140 manufacturing companies traded in Istanbul Stock Exchange (ISE) are determined as the population of the study. The list of the company names, number of all companies in each sector, number of firms chosen for representation and the size of their capital are given in Table 2.

These companies are already classified in eight sectors by ISE managers. In order to represent each sector a total of 45 manufacturing companies have been randomly chosen, to form the sample, on condition that they deliver balance sheet and income statement in Excel format and have been traded continuously in ISE, between the first quarter of 2004 and third quarter of 2009. For this purpose a list of 140 ISE traded companies, downloaded from the ISE web site, have been used. In each sector, companies have been sorted according to their capital. In order to represent each sector, comparatively small, medium and large size companies have been identified.

Six companies out of twenty-one have been chosen from the Food, Beverages and Tobacco Sector. In order to represent the Textile, Wearing Apparel and Leather sector, five companies out of nine-teen have been chosen for evaluation. There are solely two companies belonging to Manufacturing Wood, Products of Wood and Furniture sector, both are included. Paper and Paper Products, Printing and Reproduction of Recorded Media sector is represented by six companies out of thirteen.

Seven chemicals, petroleum products, rubber \& plastic products companies out of twentyone represent the sector. Non-Metallic Mineral Products sector is represented by twentyfour companies in SEC. We have chosen five of them. Similarly, five companies have been chosen to represent Basic Metals sector which comprises fourteen companies under ISE. Six out of twenty-three companies under the title Fabricated Metal Products represent the sector in our research. Lastly, all three companies as listed in Other Manufacturing Sector in SEC take place in the research.

Most of researchers point Fall of 2008 as the beginning of the crisis. Therefore, the era of 2004-2007 is accepted as pre-crisis era and named I.Period. With respect to this logic, 2008-2009 as being the crisis era, is named II.Period.

However, due to coincidental facts, we feel lucky to determine precisely the beginning of the crisis as the second half of 2007. Therefore, we have another set of pre-crisis and crisis era. Under this assumption pre-crisis era comprises 14 quarters starting with the first quarter of 2004, ending with the second quarter of 2007. This is the III.Period. The last 9 quarters make up the IV.Period, continuing from the beginning of the third quarter of 2007 to the end of third quarter of 2009.

In this study we have 23 quarters, 45 companies and 13 ratios. Totally 13455 formulas have been created by referring to several cells in the balance sheet and income statement tables of the companies. Calculated ratios have been evaluated via SPSS 17.0 by using normality test, paired samples t-test and non-parametric Mann-Whitney U-test. All results have been evaluated on $p<0.05$ significance level. The thirteen hypotheses that are tested in this study can be seen below.

1. $\mathrm{H}_{0}$ : Crisis era Current Ratio is not significantly differing from pre-crisis era.

$\mathrm{H}_{1}$ : Crisis era Current Ratio is significantly differing from pre-crisis era.

2. $\mathrm{H}_{0}$ : Crisis era Liquidity Ratio is not significantly differing from pre-crisis era.

$\mathrm{H}_{1}$ : Crisis era Liquidity Ratio is significantly differing from pre-crisis era. 
3. $\mathrm{H}_{0}$ : Crisis era Cash Ratio is not significantly differing from pre-crisis era. $\mathrm{H}_{1}$ : Crisis era Cash Ratio is significantly differing from pre-crisis era.

4. $\mathrm{H}_{0}$ : Crisis era Inventory-to-Current Assets Ratio is not significantly differing from precrisis era.

$\mathrm{H}_{1}$ : Crisis era Inventory-to-Current Assets Ratio is significantly differing from precrisis era.

5. $\mathrm{H}_{0}$ : Crisis era Short Term Receivables-to Current Assets Ratio is not significantly differing from pre-crisis era.

$\mathrm{H}_{1}$ : Crisis era Short Term Receivables-to Current Assets Ratio is significantly differing from pre-crisis era.

6. $\mathrm{H}_{0}$ : Crisis era Current Assets-to-Total Assets Ratio is not significantly differing from pre-crisis era.

$\mathrm{H}_{1}$ : Crisis era Current Assets-to-Total Assets Ratio is significantly differing from precrisis era.

7. $\mathrm{H}_{0}$ : Crisis era Short Term Liabilities-to-Total Assets Ratio is not significantly differing from pre-crisis era.

$\mathrm{H}_{1}$ : Crisis era Short Term Liabilities-to-Total Assets Ratio is significantly differing from pre-crisis era.

8. $\mathrm{H}_{0}$ : Crisis era Short Term Liabilities -to- Total Liabilities Ratio is not significantly differing from pre-crisis era.

$\mathrm{H}_{1}$ : Crisis era Short Term Liabilities -to- Total Liabilities Ratio is significantly differing from pre-crisis era.

9. $\mathrm{H}_{0}$ : Crisis era Short Term Bank Loans -to- Short Term Liabilities Ratio is not significantly differing from pre-crisis era.

$\mathrm{H}_{1}$ : Crisis era Short Term Bank Loans -to- Short Term Liabilities Ratio is significantly differing from pre-crisis era.

10. $\mathrm{H}_{0}$ : Crisis era Inventory Turnover Rate is not significantly differing from pre-crisis era.

$\mathrm{H}_{1}$ : Crisis era Inventory Turnover Rate is significantly differing from pre-crisis era.

11. $\mathrm{H}_{0}$ : Crisis era Receivables Turnover Rate is not significantly differing from pre-crisis era.

$\mathrm{H}_{1}$ : Crisis era Receivables Turnover Rate is significantly differing from pre-crisis era.

12. $\mathrm{H}_{0}$ : Crisis era Working Capital Turnover Rate is not significantly differing from precrisis era.

$\mathrm{H}_{1}$ : Crisis era Working Capital Turnover Rate is significantly differing from pre-crisis era.

13. $\mathrm{H}_{0}$ : Crisis era Net Working Capital Turnover Rate is not significantly differing from pre-crisis era.

$\mathrm{H}_{1}$ : Crisis era Net Working Capital Turnover Rate is significantly differing from precrisis era.

\section{Empirical findings}

According to Kolmogorov-Smirnov Test, data have been normally distributed for all the periods and for all the ratios. Based on paired samples t-test and Mann Whitney u-test, thirteen hypotheses that are formed for the ratios related with the working capital of real sector are tested and the findings for each ratio are given below. 


\section{a. Current ratio}

Under the assumption that pre-crisis era is straightly 2004-2007 and crisis era is 2008 2009; $\mathrm{H}_{0}$ is accepted and $\mathrm{H}_{1}$ rejected. This result does not show any difference under the assumption that the crisis really started at the beginning of the third quarter of 2007. Finally, the data have been tested for another time zone. In order to catch any immediate effect of the crisis, the last quarter of 2007 has been compared to the same quarter of 2008. Again, $\mathrm{H}_{0}$ is accepted and $\mathrm{H}_{1}$ rejected As a result, for the 45 ISE traded companies it is to be admitted that the crisis has no significant effect on current ratio.

\section{b. Liquidity ratio (acid-test ratio)}

Under the assumption that pre-crisis era is straightly 2004-2007 and crisis era is 20082009; $\mathrm{H}_{0}$ is accepted and $\mathrm{H}_{1}$ rejected. Under the assumption that the crisis really started at the beginning of the third quarter of 2007; $\mathrm{H}_{0}$ is accepted and $\mathrm{H}_{1}$ rejected. The comparison of the 4th quarter of 2007 with the 4th quarter of 2008 helps us in accepting $\mathrm{H}_{0}$ and rejecting $\mathrm{H}_{1}$. It can be concluded that liquidity ratio for the $45 \mathrm{ISE}$ traded companies has not been affected by the crisis.

\section{c. Cash ratio}

According to the results of the paired sample t-test and Mann-Whitney $U$ test, under the assumption that pre-crisis era is 2004-2007 and crisis era is 2008-2009; $\mathrm{H}_{0}$ has been accepted and $\mathrm{H}_{1}$ rejected. Since same results are valid for the other periods mentioned above, it can be said that this crisis did not affect the cash ratio for the ISE traded 45 companies.

\section{d. Inventory to current assets ratio}

Paired samples t-test implies us to reject $\mathrm{H}_{0}$ and accept $\mathrm{H}_{1}$, for the pair of pre-crisis era as 2004-2007 and crisis era as 2008-2009. However, with the alternative definition of the periods, pre-crisis era ending at the beginning of the 3 rd quarter of $2007, \mathrm{H}_{0}$ is accepted and $\mathrm{H}_{1}$ is rejected. When the last quarters of the years 2007 and 2008 are compared, again we reject the $\mathrm{H}_{0}$ and accept $\mathrm{H}_{1}$. Even though Mann-Whitney $\mathrm{U}$ test reveals that the crisis did not have any significant influence on inventory management, in the light of the other data, we may comment that inventory to current assets ratio of 45 companies traded in ISE has been affected. The comparison between the I.Period and the II.Period tells us that this is a positive impact. Sectors' average for this ratio is $32.40 \%$ before the crisis and $29.46 \%$ during the crisis. One explanation would be improved inventory management; another would be procurement/production following orders.

\section{e. Short term receivables-to current assets ratio}

According to paired samples t-test and Mann-Whitney U- test, the comparison of the I. period with the II. Period $\mathrm{H}_{0}$ is accepted and $\mathrm{H}_{1}$ is rejected. III. Period and IV. Period comparison implies us to accept $\mathrm{H}_{0}$ and reject Hypothesis $\mathrm{H}_{1}$. The last quarters of 2007 and 2008 as a pair, again $\mathrm{H}_{0}$ is accepted and $\mathrm{H}_{1}$ is rejected. Thus, we comment this ratio is not significantly affected for ISE traded 45 companies.

\section{f. Current assets-to-total assets ratio}

For all of the pairs, namely [I.Period - II.Period], [III.Period - IV.Period] and [last quarters of 2007 and 2008], $\mathrm{H}_{0}$ is accepted and $\mathrm{H}_{1}$ is rejected according to paired samples t-test and Mann-Whitney U test. Since $p$ value is above 0.05 meaning that there is no significant difference, we comment this ratio is not affected for ISE traded 45 companies. 


\section{g. Short term liabilities-to-total assets ratio}

As the Hypotheses $\mathrm{H}_{0}$ and $\mathrm{H}_{1}$ have been tested with the help of paired samples t-test, for three sets of periods namely [I.Period - II.Period], [III.Period - IV.Period] and [last quarters of 2007 and 2008] we accept $\mathrm{H}_{0}$ and reject $\mathrm{H}_{1}$. Mann-Whitney $\mathrm{U}$ test also gives the result that there is no significant difference between the pre-crisis era and crisis era ratios of the 45 ISE traded companies. With the data available and according to the result of the tests, short term liabilities-to-total assets ratio has been affected for a short period of time at the time the last crisis trod the stage and the effect faded in the course of time.

\section{h. Short term liabilities-to-total liabilities ratio}

Comments made about the tests' results of this ratio, resembles the above explained one's. Thus, for short term liabilities-to-total liabilities ratio $\mathrm{H}_{0}$ is accepted and $\mathrm{H}_{1}$ is rejected for all the periods mentioned in this study; it is interpreted that the ratio of 45 companies traded in ISE is not significantly affected.

\section{i. Short term bank loans-to-short term liabilities ratio}

Paired samples t-test imposes us to reject $\mathrm{H}_{0}$ and accept $\mathrm{H}_{1}$ for all periods of the study. Mann-Whitney $U$ test results are in the same direction. There is a meaningful influence of the crisis on the pair of I.Period - II.Period. Similarly, under the assumption that the crisis era starts in the second half of 2007 , the crisis has significant impact on this ratio. Before the crisis the ratio of the 45 companies analyzed in this study was $28.49 \%$ on the average. During the crisis it rose to $38.95 \%$. In the light of this data we may comment that this ratio has been affected by the crisis.

\section{j. Inventory turnover ratio}

As can be followed from the relevant tables, the tests executed enable the acceptance of the $\mathrm{H}_{0}$ and rejection of $\mathrm{H}_{1}$ for all period pairs [I.Period - II.Period], [III.Period IV.Period] and [last quarters of 2007 and 2008]

\section{k. Receivables turnover ratio}

This ratio is one of the few crisis affected ratios. Even though paired samples t-test shows no significant difference between any of the periods of this study and tells us to accept $\mathrm{H}_{0}$ and reject $\mathrm{H}_{1}$, Mann-Whitney $\mathrm{U}$ Test results differ. Under the assumption that the years between 2004-2007 comprise the pre-crisis era, and the years 2008-2009 are crisis era; $\mathrm{H}_{0}$ is to be rejected and $\mathrm{H}_{1}$ to be accepted. For the 45 companies traded in ISE, $p$ has the value below 0.05, thus there is significant effect of the crisis on Receivables Turnover Rate. During the crisis receivables turnover ratio become 5.04, whereas it was 15.8 before the crisis. This means that trade receivables are collected at a slower pace.

\section{Working capital turnover ratio}

Paired samples t-test imposes us to accept $\mathrm{H}_{0}$ and reject $\mathrm{H}_{1}$ for the I.Period-II.Period and III.Period-IV.Period pairs, but it is just the opposite for the last quarters of the years 2007 and 2008. Thus we accept $\mathrm{H}_{1}$ and reject $\mathrm{H}_{0}$ for this specific period. On the other hand, Mann-Whitney $\mathrm{U}$ test tells us to reject $\mathrm{H}_{0}$ and accept $\mathrm{H}_{1}$ for the pair of I. Period - II. Period. As can be followed from Table 3, working capital turnover ratio was 1.61 and deteriorated to 1.45 during the crisis. With $p$ value under 0.05 meaning significant difference before and during the crisis era, it is to be agreed upon the fact that working capital rate of 45 companies traded in ISE is impacted. 


\section{m. Net working capital turnover ratio}

Whatever interpretation is done for the preceding ratio, it is not valid for the net working capital turnover ratio. For all the periods mentioned in this study, $\mathrm{H}_{0}$, that the ratio is not significantly affected by the crisis is accepted. The result is supported both by paired samples t-test and Mann-Whitney U test. Therefore, it would not be wrong, commenting that the 2008 crisis has not affected this ratio of the 45 companies having been uninterruptedly traded in ISE since the first quarter of 2004.

According to the study on ISE, within the frame of the two statistical methods, significant but limited impact is identified in five ratios out of thirteen. Crisis affected ratios for 45 companies traded in ISE are summarized in Table 3.

\section{Conclusion}

This study found evidence that the recent crisis affected the ISE traded companies on a limited basis. Therefore, future research and study is recommended. First, the year 2009 is to be completed. Another set of research should follow including post-crisis era at the moment we decide this crisis is over.

As can be seen in Table 3, receivables turnover ratio is one of the most affected ratios among others. It was 15.18 times during the pre-crisis but it dropped to 5.04 during the crisis era. The reason for this important decline is related the drop in sales figures of real sector during the economic crisis.

Other ratios are not affected as much as receivables turnover ratio during the economic crisis. There are two important factors for this result. Interest rates dropped due to the decline in expected inflation during the GEC. The other reason is the credit easing during the economic crisis. As can be seen in Table 3, short term bank loan to short term liabilities ratio was $28.49 \%$ during the pre-crisis era but it increased to $38.95 \%$ during the crisis era. Since interest rates have declined and credit amount increased during the crisis, firms in the real sector responded to the impact of GEC by taking more debt from the banks.

Since capital outflows did not continue for a long period of time, capital inflows to Turkey have restarted, Turkish Lira did not appreciate too much against foreign currencies. Therefore, inflation is not affected too much from GEC. When unemployment figure jumped from $10.3 \%$ in the second period of 2008 to $15.8 \%$ in the first period of 2009 , the inflation rate dropped from $10.61 \%$ in the second period of 2008 to $5.73 \%$ in the second period of 2009 due the decrease in the demand. Thus, central bank decreased the interest rate from $16.25 \%$ in the second period of 2008 to $8.75 \%$ in the second period of 2009 . This has also affected interest rates of loans. As a result, this limited impact on the working capital of real sector is based on these positive developments (decrease in interest rates and increase in credit amount) in Turkish macro economy.

Today, there is too much hot money in the global economy. According to Chinese Vice Finance Minister Zhu Guangyao, the amount of hot money flowing around before GEC was 9 trillion dollar, and it is 10 trillion dollar after GEC (Forthe, 2010). This amount of money creates asset bubbles in all over the world. Federal Reserve is expected to initiate a second quantitative easing in order to boost growth. China struggles with inflation due to intensive capital inflows. Finally, some of the European countries (Ireland, Portuguese, Spain, and Greece) have debt problem. Since capital inflows restarted after GEC, it would not be wrong to say that the real sector of Turkey is not affected too much from the crisis. But same macro and micro financial results should not be expected in the future due this current global economic outlook. In other words, asset bubble can burst and most of the working capital ratios of real sector can be deeply affected in the future due to these important developments in the world economy. This is not only true for Turkey, but also for all the emerging economies. 
If we compare the economic indicators presented in Table 1 with our empirical findings, it would not be wrong to argue that GEC did not affect the working capital of Turkish firms, due to the short term maturity characteristics of the economic crisis and the drop in the interest rates. When there were huge cash outflows during the economic crises in 1994 and 2001, interest rates and inflation both increased considerably. However, the interest rates and inflation decreased during GEC. Therefore, working capital of ISE traded Turkish firms is not affected too much, but this does not mean that the same economic results will occur in the future.

If firms do not want to encounter cash flow problems in the future, they need to be careful in managing their short-term assets and liabilities. Companies which manage their working capital optimally during times of recessions come out stronger after the recession period. Working capital management is one of the cornerstones of business continuity and acts as a hedge against tightening credit and access to additional capital. This study showed us that firms did not have important liquidity problems during the GEC, but this does not mean that capital inflows will go on in the future. For example, economic crisis in 1994 and 2001 in Turkey has shown us that firms, that managed their working capital poorly, had very difficult times during these economic crises.

\section{References}

Cali, M., Massa, I., and Te Velde, D., 2008. “The global financial crisis: Financial flows to developing countries set to fall by one quarter," ODI Report. London: Overseas Development Institute, available at www.odi.org.uk/resources/detailsasp?id=2523\&title=global-financial-crisis-financial-flows-developing-countries-setfall-byone-quarter.

Calvo, G., Isquierdo, A., Mejia, L., 2008. "Systemic sudden stops: The relevance of balance sheet effects and financial integration," Inter-American Development Bank, Working Paper No637, available at http://www.iadb.org/lacdebtgroup/ docs/izquierdo_systemic_sudden_stops.pdf.

Chiou, Jeng-Ren, Li Cheng and Han-Wen Wu, 2006. "The determinants of working capital management," Journal of American Academy of Business, Cambridge. Vol.10, Iss.1, Hollywood. pp.149-55.

Dogan, D., 2005. “Turkey's 2001 Financial crisis and it’s effect on firms: An application taken place in SEC," (Unpublished Master Thesis, Süleyman Demirel University, The Institute for Graduate Studies in Social Sciences), Isparta, Turkey.

Filbeck, G. and Krueger, T., 2005. “An analysis of working capital management results across industries,” Mid - American Journal of Business, Vol.20, Iss.2, Muncie, pp.11-18.

Forsthe, M., 2010. "China says Fed easing may flood world with hot money," available at http://www.bloomberg.com/news/2010-11-08/fed-easing-may-flood-world-economy-with-hot-money-chinese-officialsays.html.

Gunay, S., 2002. "The impact of recent economic crisis on the capital structure of Turkish corporations and the test of static trade-off theory: Implications for corporate governance system,” VI International Conference in Economics, Economic Research Center/METU, Ankara, Turkey.

Jacob, J., Chander, P., 2009. “Economic slowdown and Indian firms: An Overview," The Journal for Decision Makers, 34 (3). pp.59-66.

Özatay, F., 2009. Financial crises and Turkey, 1st Addition, Istanbul, Dogan Kitap.

Strischek, D., 2001. “A banker's perspective on working capital and cash flow management," Strategic Finance, Vol.83, Iss.4, Montvale. pp.38-45.

Te Velde, D., 2008. The global financial crisis and the developing countries. ODI Background Note. London: Overseas Development Institute, available at http://www.odi.org.uk/resources/download/2462.pdf.

Yang, W., ve Young, K., 2009. “Impacts of the U.S. financial crisis on the Korean economy,” Harvard Asia Quarterly, 12(1), Cambridge, MA. pp.35-45. 


\section{Appendix}

TABLE 1. TURKEY'S ECONOMIC INDICATORS (2007 - 2010)

\begin{tabular}{lcccccc}
\hline Quarters & $\begin{array}{c}\text { Yearly } \\
\text { Inflation } \\
\text { Rate (CPI) }\end{array}$ & $\begin{array}{c}\text { CBRT } \\
\text { Interest } \\
\text { Rate }\end{array}$ & $\begin{array}{c}\text { Dollar / } \\
\text { Turkish Lira }\end{array}$ & $\begin{array}{c}\text { Yearly Current } \\
\text { Account Deficit } \\
\text { (Million Dollars) }\end{array}$ & $\begin{array}{c}\text { Unemployment } \\
\text { Rate }\end{array}$ & $\begin{array}{c}\text { GDP } \\
\text { Growth Rate }\end{array}$ \\
\hline 2007 (4. Quarter) & 8.39 & 15.75 & 1.16 & 38.0 & 10.6 & 3.4 \\
\hline 2008 (1. Quarter) & 9.15 & 15.25 & 1.32 & 41.0 & 10.7 & 7.0 \\
\hline 2008 (2. Quarter) & 10.61 & 16.25 & 1.23 & 44.4 & 9.0 & 2.6 \\
\hline 2008 (3. Quarter) & 11.13 & 16.75 & 1.26 & 48.5 & 10.3 & 0.9 \\
\hline 2008 (4. Quarter) & 10.06 & 15.00 & 1.53 & 41.6 & 13.6 & -7.0 \\
\hline 2009 (1. Quarter) & 7.89 & 10.50 & 1.67 & 31.3 & 15.8 & -14.6 \\
\hline 2009 (2. Quarter) & 5.73 & 8.75 & 1.54 & 20.9 & 13.0 & -7.6 \\
\hline 2009 (3. Quarter) & 5.27 & 7.25 & 1.50 & 15.4 & 13.4 & -2.7 \\
\hline 2009 (4. Quarter) & 6.53 & 6.50 & 1.52 & 14.0 & 13.5 & 6.0 \\
\hline 2010 (1. Quarter) & 9.56 & 6.50 & 1.52 & 22.1 & 13.7 & 11.7 \\
\hline 2010 (2. Quarter) & 8.37 & 6.25 & 1.58 & 27.3 & 10.5 & 10.3 \\
\hline
\end{tabular}

Source: Turkish Statistical Institution, Central Bank of the Republic of Turkey (CBRT), Republic of Turkey Ministry of Finance. Note: CPI - Consumer Price Index; GDP - Gross Domestic Product.

TABLE 2. THE LIST OF MANUFACTURING INDUSTRY COMPANIES TRADED IN ISE, CHOSEN FOR RATIO ANALYSIS

\begin{tabular}{|c|c|c|}
\hline $\begin{array}{l}\text { Chosen/ } \\
\text { Total }^{*}\end{array}$ & Capital (TL) & Name of the sector \\
\hline $6 / 21$ & & 31 - Food, Beverages And Tobacco \\
\hline & $450,000,000$ & Anadolu Efes Biracilik Ve Malt Sanayii \\
\hline & $268,650,000$ & Ülker Bisküvi Sanayi \\
\hline & $100,000,000$ & Tukas Gida Sanayi Ve Ticaret Izmir \\
\hline & $44,951,051$ & Pinar Süt Mamulleri Sanayii Izmir \\
\hline & $27,639,480$ & Altinyag Kombinalari \\
\hline & $22,000,000$ & Seker Piliç Ve Yem Sanayi Ticaret \\
\hline $5 / 19$ & & 32 - Textile, Wearing Apparel And Leather \\
\hline & $194,529,076$ & $\begin{array}{l}\text { Kordsa Global Endüstriyel Iplik Ve Kord Bezi San. Ve } \\
\text { Tic. }\end{array}$ \\
\hline & $160,000,000$ & Vakko Tekstil Ve Hazir Giyim Sanayi Isletmeleri \\
\hline & $30,014,121$ & Ak-Al Tekstil Sanayi \\
\hline & $17,010,000$ & Yatas Yatak Ve Yorgan Sanayi Ticaret \\
\hline & $5,400,000$ & $\begin{array}{l}\text { Derimod Konfeksiyon Ayakkabi-Deri Sanayi Ve } \\
\text { Ticaret }\end{array}$ \\
\hline $2 / 2$ & & $\begin{array}{l}33 \text { - Manufacture Of Wood, Products Of Wood \& } \\
\text { Furniture }\end{array}$ \\
\hline & $58,631,040$ & Gentas Genel Metal Sanayi Ve Ticaret \\
\hline & $50,000,000$ & Kelebek Mobilya Sanayi Ve Ticaret \\
\hline $6 / 13$ & & $\begin{array}{l}34 \text { - Paper And Paper Products, Printing \& } \\
\text { Reproduction Of Recorded Media }\end{array}$ \\
\hline & $460,000,000$ & Hürriyet Gazetecilik Ve Matbaacilik \\
\hline & $100,000,000$ & $\begin{array}{l}\text { Tire Kutsan Oluklu Mukavva, Kutu Ve Kagit Sanayi } \\
\text { Tire }\end{array}$ \\
\hline & $65,000,000$ & Viking Kagit Ve Selüloz Izmir \\
\hline & $52,500,000$ & Alkim Kagit Sanayi Ve Ticaret \\
\hline & $9,000,000$ & Bak Ambalaj Sanayi Ve Ticaret \\
\hline
\end{tabular}




\begin{tabular}{|c|c|c|}
\hline $\begin{array}{l}\text { Chosen/ } \\
\text { Total }{ }^{*}\end{array}$ & Capital (TL) & Name of the sector \\
\hline & $4,800,000$ & Kaplamin Ambalaj Sanayi Ve Ticaret Izmir \\
\hline $7 / 21$ & & $\begin{array}{l}35 \text { - Chemicals, Petroleum Products, Rubber \& Plastic } \\
\text { Products }\end{array}$ \\
\hline & $577,500,000$ & Petrol Ofisi Ankara \\
\hline & $548,208,000$ & $\begin{array}{l}\text { Eis Eczacibasi Ilaç, Sinai Ve Finansal Yatirimlar San } \\
\text { Ve Tic }\end{array}$ \\
\hline & $300,000,000$ & Aygaz \\
\hline & $185,000,000$ & Aksa Akrilik Kimya Sanayii \\
\hline & $144,000,000$ & Deva Holding \\
\hline & $75,857,033$ & Hektas Ticaret Türk \\
\hline & $7,441,875$ & Brisa Bridgestone Sabanci Lastik San. Ve Tic. \\
\hline $5 / 24$ & & 36 - Non-Metalic Mineral Products \\
\hline & $580,000,000$ & Trakya Cam Sanayi \\
\hline & $191,447,068$ & Akçansa Çimento Sanayi Ve Ticaret \\
\hline & $112,830,900$ & Eczacibasi Yapi Gereçleri Sanayi Ve Ticaret \\
\hline & $28,512,000$ & Kütahya Porselen Sanayii Kütahya \\
\hline & $10,500,000$ & Haznedar Refrakter Sanayi \\
\hline $5 / 14$ & & 37 - Basic Metals \\
\hline & $\begin{array}{l}1,148,812,50 \\
0\end{array}$ & Eregli Demir Ve Çelik Fabrikalari \\
\hline & $100,975,680$ & Cemtas Çelik Makina Sanayi Ve Ticaret \\
\hline & $34,000,000$ & Fenis Alüminyum Sanayi Ve Ticaret \\
\hline & $16,500,000$ & Çelik Halat Ve Tel Sanayii \\
\hline & $5,220,000$ & Erbosan Erciyas Boru San. Ve Tic. Kayseri \\
\hline $6 / 23$ & & 38 - Fabricated Metal Products \\
\hline & $675,728,205$ & Arçelik \\
\hline & $500,000,000$ & Tofas Türk Otomobil Fabrikasi \\
\hline & $335,456,275$ & Vestel Elektronik Sanayi Ve Ticaret \\
\hline & $112,233,652$ & Türk Prysmian Kablo Ve Sistemleri Mudanya \\
\hline & $54,000,000$ & Türk Demir Döküm Fabrikalari \\
\hline & $15,000,000$ & Klimasan Klima Sanayi Ve Ticaret \\
\hline $3 / 3$ & & 39 - Other Manufacturing \\
\hline & $80,000,000$ & Goldas Kuyumculuk Sanayi Ithalat Ve ihr \\
\hline & $7,875,000$ & Adel Kalemcilik Ticaret Ve Sanayi \\
\hline & $7,250,000$ & Serve Kirtasiye Sanayi Ve Ticaret \\
\hline
\end{tabular}

Note: * The 1st number, 1st column shows the number of companies chosen from the sector, 2nd number is the total of sector; Companies chosen make up $32.4 \%$ of 140 companies traded in ISE. $(45 / 140=0.324)$

TABLE 3. AFFECTED WORKING CAPITAL RATIOS

\begin{tabular}{lcc}
\hline Affected ratios & Pre-crisis era & Crisis era \\
\hline Inventory Ratio & $32.40 \%$ & $29.46 \%$ \\
\hline $\begin{array}{l}\text { Short Term Bank Loans to } \\
\text { Short Term Liabilities Ratio }\end{array}$ & $28.49 \%$ & $38.95 \%$ \\
\hline Inventory Turnover Ratio & 4.88 times & 6.52 times \\
\hline Receivables Turnover Ratio & 15.18 times & 5.04 times \\
\hline $\begin{array}{l}\text { Working Capital Turnover } \\
\text { Ratio }\end{array}$ & 1.61 times & 1.45 times \\
\hline
\end{tabular}


TABLE 4. RATIO AVERAGES FOR 45 ISE TRADED COMPANIES

\begin{tabular}{|c|c|c|c|c|c|}
\hline & & $\begin{array}{cc}2004- & 2008- \\
2007 & 2009 \\
\text { Average } & \text { Average }\end{array}$ & $\begin{array}{l}2004- \\
2007^{\star} \\
\text { Average }\end{array}$ & $\begin{array}{l}2007^{\star \star}- \\
2009 \\
\text { Average }\end{array}$ & $\begin{array}{l}\text { All Years' } \\
\text { Average }\end{array}$ \\
\hline Current Ratio & $\begin{array}{l}\text { Current Assets / ST } \\
\text { Liabilities }\end{array}$ & $203.97 \% 205.33 \%$ & $201.94 \%$ & $208.19 \%$ & $204.39 \%$ \\
\hline Liquidity Ratio & $\begin{array}{l}\text { (Current Assets- } \\
\text { Inventory-Prepaid } \\
\text { Expenses-Other Current } \\
\text { Assets) / Short Term } \\
\text { Liabilities }\end{array}$ & $134.40 \% 134.29 \%$ & $133.58 \%$ & $135.58 \%$ & $134.36 \%$ \\
\hline Cash Ratio & $\begin{array}{l}\text { (Liquid Assets + } \\
\text { Securities) / Short Term } \\
\text { Liabilities }\end{array}$ & $41.69 \% \quad 31.48 \%$ & $43.61 \%$ & $30.77 \%$ & $38.58 \%$ \\
\hline Inventory Ratio & $\begin{array}{l}\text { Inventory / Current } \\
\text { Assets }\end{array}$ & $32.40 \% \quad 29.46 \%$ & $32.27 \%$ & $30.31 \%$ & $31.50 \%$ \\
\hline $\begin{array}{l}\text { S.T. } \\
\text { Receivables } \\
\text { Ratio }\end{array}$ & $\begin{array}{l}\text { Short Term } \\
\text { Receivables /Current } \\
\text { Assets }\end{array}$ & $51.19 \% \quad 51.52 \%$ & $51.01 \%$ & $51.73 \%$ & $51.29 \%$ \\
\hline $\begin{array}{l}\text { Current Assets } \\
\text { Ratio }\end{array}$ & $\begin{array}{l}\text { Current Assets / Total } \\
\text { Assets }\end{array}$ & $54.74 \% \quad 56.37 \%$ & $54.36 \%$ & $56.59 \%$ & $55.23 \%$ \\
\hline $\begin{array}{l}\text { S.T. Liabilities } \\
\text { Ratio } 1\end{array}$ & $\begin{array}{l}\text { ST Liabilities / Total } \\
\text { Assets }\end{array}$ & $33.88 \% \quad 37.07 \%$ & $34.01 \%$ & $36.15 \%$ & $34.85 \%$ \\
\hline $\begin{array}{l}\text { S.T. Liabilities } \\
\text { Ratio } 2\end{array}$ & $\begin{array}{l}\text { ST Liabilities / Total } \\
\text { Liabilities }\end{array}$ & $73.74 \% \quad 74.22 \%$ & $73.73 \%$ & $74.13 \%$ & $73.89 \%$ \\
\hline $\begin{array}{l}\text { S.T. Liabilities } \\
\text { Ratio } 3\end{array}$ & $\begin{array}{l}\text { Short Term Bank Loans / } \\
\text { S.T. Liabilities }\end{array}$ & $28.49 \% \quad 38.95 \%$ & $28.24 \%$ & $37.02 \%$ & $31.67 \%$ \\
\hline $\begin{array}{l}\text { Inventory } \\
\text { Turnover Ratio }\end{array}$ & $\begin{array}{l}\text { Cost of Goods Sold / } \\
\text { Inventory }\end{array}$ & 4.88 & 4.58 & 6.62 & 5.38 \\
\hline $\begin{array}{l}\text { Receivables } \\
\text { Turnover Ratio }\end{array}$ & $\begin{array}{l}\text { Net Sales / (ST Trade } \\
\text { Receivables + Long } \\
\text { Term Trade } \\
\text { Receivables) }\end{array}$ & 15.18 & 9.13 & 16.71 & 12.09 \\
\hline $\begin{array}{l}\text { Work. Cap. Turn } \\
\text { Ratio }\end{array}$ & $\begin{array}{l}\text { Net Sales / Current } \\
\text { Assets }\end{array}$ & 1.61 & 1.51 & 1.64 & 1.56 \\
\hline $\begin{array}{l}\text { Net Work. Cap. } \\
\text { Turn. Ratio }\end{array}$ & $\begin{array}{l}\text { Net Sales / } \\
\text { (Current Assets - Short } \\
\text { Term Liabilities) }\end{array}$ & 2.57 & 2.02 & 2.20 & 2.09 \\
\hline
\end{tabular}

Source: All the information in the table is based on the data downloaded from ISE web site. Note: ${ }^{*}$ - End of the second quarter; ${ }^{* *}$ - From the beginning of the third quarter. 
TABLE 5. THE SECTOR SPECIFIC AVERAGES OF RATIOS FOR THE DEFINED PERIODS

\begin{tabular}{|c|c|c|c|c|c|}
\hline Sectors & $\begin{array}{c}2004- \\
2007 \\
\text { Average }\end{array}$ & $\begin{array}{c}2008- \\
2009 \\
\text { Average }\end{array}$ & $\begin{array}{l}2004- \\
2007^{\star} \\
\text { Average }\end{array}$ & $\begin{array}{c}2007^{\star *}- \\
2009 \\
\text { Average }\end{array}$ & $\begin{array}{c}\text { All } \\
\text { Years' } \\
\text { Average }\end{array}$ \\
\hline \multicolumn{6}{|c|}{ CURRENT RATIO (percentages) } \\
\hline Food, beverages and tobacco & 123.80 & 110.08 & 122.82 & 114.66 & 119.62 \\
\hline Textile, Wearing Apparel and Leather & 198.82 & 227.92 & 200.68 & 218.56 & 207.68 \\
\hline Manufacture of Wood, Products of Wood \& Furniture & 334.55 & 417.17 & 314.43 & 430.10 & 359.69 \\
\hline $\begin{array}{l}\text { Paper and Paper Products, Printing \&Reproduction of Recorded } \\
\text { Media }\end{array}$ & 178.45 & 159.67 & 177.30 & 165.62 & 172.73 \\
\hline Chemicals, Petroleum Products, Rubber and Plastic Products & 224.52 & 218.46 & 217.58 & 230.60 & 222.68 \\
\hline Non-metallic Mineral Products & 203.15 & 176.75 & 209.12 & 173.32 & 195.11 \\
\hline Basic Metals & 301.97 & 333.86 & 297.91 & 333.09 & 311.68 \\
\hline Fabricated Metal Products & 146.35 & 130.04 & 148.42 & 130.43 & 141.38 \\
\hline Other Manufacturing & 242.29 & 261.59 & 235.16 & 268.40 & 248.17 \\
\hline \multicolumn{6}{|c|}{ LIQUIDITY RATIO (percentages) } \\
\hline Food, beverages and tobacco & 79.15 & 70.02 & 78.86 & 72.50 & 76.37 \\
\hline Textile, Wearing Apparel and Leather & 130.51 & 153.46 & 131.62 & 146.62 & 137.49 \\
\hline Manufacture of Wood, Products of Wood \& Furniture & 226.22 & 245.09 & 215.61 & 257.41 & 231.96 \\
\hline $\begin{array}{l}\text { Paper and Paper Products, Printing \&Reproduction of Recorded } \\
\text { Media }\end{array}$ & 124.74 & 114.45 & 123.69 & 118.36 & 121.61 \\
\hline Chemicals, Petroleum Products, Rubber and Plastic Products & 156.33 & 154.53 & 149.95 & 164.85 & 155.78 \\
\hline Non-metallic Mineral Products & 133.34 & 100.73 & 138.69 & 99.66 & 123.41 \\
\hline Basic Metals & 193.72 & 217.64 & 192.39 & 214.39 & 201.00 \\
\hline Fabricated Metal Products & 100.22 & 89.24 & 102.04 & 88.84 & 96.88 \\
\hline Other Manufacturing & 129.54 & 156.58 & 129.75 & 150.25 & 137.77 \\
\hline \multicolumn{6}{|c|}{ CASH RATIO (percentages) } \\
\hline Food, beverages and tobacco & 13.57 & 12.85 & 13.76 & 12.71 & 13.35 \\
\hline Leather & 29.61 & 26.77 & 32.00 & 23.69 & 28.75 \\
\hline Manufacture of Woo & 286.28 & 71.07 & 317.22 & 70.77 & 220.78 \\
\hline $\begin{array}{l}\text { Paper and Paper Products, Printing \& Reproduction of } \\
\text { Recorded Media }\end{array}$ & 23.85 & 27.49 & 24.34 & 25.91 & 24.96 \\
\hline Chemicals, Petroleum Products, Rubber and Plastic Products & 49.06 & 49.60 & 47.30 & 52.21 & 49.22 \\
\hline Non-metallic Mineral Products & 35.79 & 19.41 & 38.75 & 18.44 & 30.80 \\
\hline Basic Metals & 41.90 & 59.48 & 42.73 & 54.29 & 47.25 \\
\hline Fabricated Metal Products & 21.88 & 14.88 & 22.97 & 14.74 & 19.75 \\
\hline Other Manufacturing & 22.45 & 22.47 & 20.77 & 25.08 & 22.46 \\
\hline \multicolumn{6}{|c|}{ INVENTORY / CURRENT ASSETS (percentages) } \\
\hline Food, beverages and tobacco & 34.86 & 32.39 & 34.86 & 32.93 & 34.11 \\
\hline Textile, Wearing Apparel and Leather & 33.92 & 29.27 & 34.42 & 29.52 & 32.50 \\
\hline Manufacture of Wood, Products of Wood \& Furniture & 38.46 & 48.58 & 38.08 & 46.93 & 41.54 \\
\hline $\begin{array}{l}\text { Paper and Paper Products, Printing \&Reproduction of Recorded } \\
\text { Media }\end{array}$ & 28.64 & 23.66 & 28.60 & 24.83 & 27.13 \\
\hline Chemicals, Petroleum Products, Rubber and Plastic Products & 26.39 & 23.57 & 26.43 & 24.13 & 25.53 \\
\hline Non-metallic Mineral Products & 35.28 & 40.05 & 34.83 & 39.69 & 36.73 \\
\hline Basic Metals & 33.51 & 30.73 & 33.37 & 31.55 & 32.66 \\
\hline Fabricated Metal Products & 28.32 & 24.69 & 28.03 & 25.94 & 27.21 \\
\hline Other Manufacturing & 43.96 & 26.25 & 42.95 & 31.76 & 38.57 \\
\hline \multicolumn{6}{|c|}{ SHORT TERM RECEIVABLES / CURRENT ASSETS (percentages) } \\
\hline Food, beverages and tobacco & 52.10 & 47.41 & 51.74 & 49.01 & 50.67 \\
\hline Textile, Wearing Apparel and Leather & 50.05 & 58.34 & 48.62 & 58.72 & 52.57 \\
\hline Manufacture of Wood, Products of Wood \& Furniture & 41.97 & 34.59 & 41.58 & 36.84 & 39.72 \\
\hline $\begin{array}{l}\text { Paper and Paper Products, Printing \& Reproduction of } \\
\text { Recorded Media }\end{array}$ & 61.16 & 56.11 & 61.36 & 56.93 & 59.63 \\
\hline Chemicals, Petrol & 50.38 & 46.73 & 50.38 & 47.54 & 49.21 \\
\hline
\end{tabular}


The impact of the global economic crisis on working capital of real sector in Turkey I BEH, January 2011

\begin{tabular}{|c|c|c|c|c|c|}
\hline Sectors & $\begin{array}{c}2004- \\
2007\end{array}$ & $\begin{array}{c}2008- \\
2009\end{array}$ & $\begin{array}{l}2004- \\
2007^{*}\end{array}$ & $\begin{array}{l}2007^{\star *}- \\
2009\end{array}$ & $\begin{array}{c}\text { All } \\
\text { Years' }\end{array}$ \\
\hline & Average & Average & Average & Average & Average \\
\hline Non-metallic Mineral Products & 46.24 & 46.70 & 45.84 & 47.22 & 46.38 \\
\hline Basic Metals & 48.41 & 48.70 & 48.34 & 48.75 & 48.50 \\
\hline Fabricated Metal Products & 53.99 & 55.44 & 53.88 & 55.29 & 54.43 \\
\hline Other Manufacturing & 46.69 & 66.46 & 47.90 & 60.18 & 52.71 \\
\hline \multicolumn{6}{|c|}{ CURRENT ASSETS / TOTAL ASSETS (percentages) } \\
\hline Food, beverages and tobacco & 44.77 & 44.09 & 43.01 & 46.99 & 44.57 \\
\hline Textile, Wearing Apparel and Leather & 63.33 & 68.37 & 62.37 & 68.75 & 64.87 \\
\hline Manufacture of Wood, Products of Wood \& Furniture & 64.77 & 60.36 & 65.25 & 60.59 & 63.43 \\
\hline $\begin{array}{l}\text { Paper and Paper Products, Printing \& Reproduction of } \\
\text { Recorded Media }\end{array}$ & 38.94 & 39.35 & 39.16 & 38.90 & 39.06 \\
\hline Chemicals, Petroleum Products, Rubber and Plastic Products & 47.53 & 49.95 & 47.20 & 49.92 & 48.26 \\
\hline Non-metallic Mineral Products & 47.37 & 50.52 & 47.08 & 50.27 & 48.33 \\
\hline Basic Metals & 64.72 & 64.71 & 65.01 & 64.26 & 64.71 \\
\hline Fabricated Metal Products & 67.72 & 66.63 & 67.90 & 66.60 & 67.39 \\
\hline Other Manufacturing & 71.75 & 82.63 & 70.89 & 81.55 & 75.06 \\
\hline \multicolumn{6}{|c|}{ SHORT TERM LIABILITIES / TOTAL ASSETS (percentages) } \\
\hline Food, Beverages and Tobacco & 38.15 & 45.47 & 38.60 & 43.15 & 40.38 \\
\hline Textile, Wearing Apparel and Leather & 34.69 & 39.73 & 33.62 & 40.27 & 36.22 \\
\hline Manufacture of Wood, Products of Wood \& Furniture & 63.28 & 30.64 & 67.25 & 31.71 & 53.34 \\
\hline $\begin{array}{l}\text { Paper and Paper Products, Printing \& Reproduction of } \\
\text { Recorded Media }\end{array}$ & 24.52 & 31.50 & 24.66 & 29.73 & 26.65 \\
\hline Chemicals, Petroleum Products, Rubber and Plastic Products & 25.28 & 26.87 & 26.01 & 25.38 & 25.76 \\
\hline Non-metallic Mineral Products & 28.62 & 34.93 & 27.98 & 34.52 & 30.54 \\
\hline Basic Metals & 27.75 & 27.24 & 28.23 & 26.60 & 27.59 \\
\hline Fabricated Met & 47.41 & 52.36 & 46.93 & 52.02 & 48.92 \\
\hline Other Manufacturing & 35.03 & 44.47 & 34.57 & 43.09 & 37.90 \\
\hline \multicolumn{6}{|c|}{ SHORT TERM LIABILITIES / TOTAL LIABILITIES (percentages) } \\
\hline Food, beverages and tobacco & 67.55 & 74.62 & 67.49 & 73.14 & 69.70 \\
\hline Textile, Wearing Apparel and Leather & 74.91 & 79.11 & 74.15 & 79.36 & 76.19 \\
\hline Manufacture of Wood, Products of Wood \& Furniture & 86.72 & 88.34 & 86.69 & 88.03 & 87.22 \\
\hline $\begin{array}{l}\text { Paper and Paper Products, Printing \& Reproduction of } \\
\text { Recorded Media }\end{array}$ & 67.99 & 64.44 & 67.14 & 66.55 & 66.91 \\
\hline Chemicals, Petroleum Products, Rubber and Plastic Pro & 71.56 & 74.30 & 71.66 & 73.52 & 72.39 \\
\hline Non-metallic Mineral Products & 71.88 & 69.13 & 72.27 & 69.14 & 71.04 \\
\hline Basic Metals & 70.12 & 69.66 & 70.45 & 69.24 & 69.98 \\
\hline Fabricated Metal Products & 81.09 & 75.65 & 81.54 & 76.15 & 79.43 \\
\hline Other Manufacturing & 86.59 & 88.37 & 87.11 & 87.18 & 87.14 \\
\hline \multicolumn{6}{|c|}{ SHORT TERM BANK LOANS / SHORT TERM LIABILITIES (percentages) } \\
\hline Food, beverages and tobacco & 35.53 & 41.91 & 37.01 & 38.20 & 37.47 \\
\hline Textile, Wearing Apparel and Leather & 27.47 & 43.37 & 27.07 & 40.46 & 32.31 \\
\hline Manufacture of Wood, Products of Wood \& Furniture & 29.25 & 32.90 & 29.25 & 32.10 & 30.36 \\
\hline $\begin{array}{l}\text { Paper and Paper Products, Printing \& Reproduction of } \\
\text { Recorded Media }\end{array}$ & 35.52 & 46.01 & 35.21 & 44.17 & 38.71 \\
\hline Chemicals, Petroleum Products, Rubber and Plastic Products & 23.82 & 34.14 & 24.68 & 30.51 & 26.96 \\
\hline Non-metallic Mineral Products & 34.17 & 55.47 & 31.26 & 55.27 & 40.65 \\
\hline Basic Metals & 21.45 & 30.07 & 21.76 & 27.67 & 24.07 \\
\hline Fabricated Metal Products & 23.19 & 36.17 & 21.52 & 35.88 & 27.14 \\
\hline Other Manufacturing & 25.28 & 19.66 & 25.49 & 20.58 & 23.57 \\
\hline \multicolumn{6}{|c|}{ INVENTORY TURNOVER RATE (times) } \\
\hline Food, beverages and tobacco & 5.56 & 8.07 & 5.24 & 8.01 & 6.32 \\
\hline Textile, Wearing Apparel and Leather & 5.48 & 2.99 & 4.77 & 4.66 & 4.73 \\
\hline Manufacture of Wood, Products of Wood \& Furniture & 2.11 & 1.27 & 2.11 & 1.47 & 1.86 \\
\hline $\begin{array}{l}\text { Paper and Paper Products, Printing \& Reproduction of } \\
\text { Recorded Media }\end{array}$ & 5.60 & 5.76 & 5.29 & 6.20 & 5.65 \\
\hline Chemicals, Petroleum Products, Rubber and Plastic Products & 6.29 & 5.60 & 5.96 & 6.27 & 6.08 \\
\hline Non-metallic Mineral Products & 2.75 & 2.13 & 2.61 & 2.48 & 2.56 \\
\hline
\end{tabular}




\begin{tabular}{|c|c|c|c|c|c|}
\hline Sectors & $\begin{array}{c}2004- \\
2007\end{array}$ & $\begin{array}{c}2008- \\
2009\end{array}$ & $\begin{array}{l}2004- \\
2007^{\star}\end{array}$ & $\begin{array}{l}2007^{\star *}- \\
2009\end{array}$ & $\begin{array}{c}\text { All } \\
\text { Years' }\end{array}$ \\
\hline & Average & Average & Average & Average & Average \\
\hline Basic Metals & 4.67 & 5.19 & 4.33 & 5.61 & 4.83 \\
\hline Fabricated Metal Products & 4.01 & 3.99 & 3.84 & 4.26 & 4.00 \\
\hline Other Manufacturing & 5.25 & 31.08 & 5.11 & 25.56 & 13.11 \\
\hline \multicolumn{6}{|c|}{ RECEIVABLES TURNOVER RATE (times) } \\
\hline Food, beverages and tobacco & 12.16 & 13.57 & 11.30 & 14.58 & 12.59 \\
\hline Textile, Wearing Apparel and Leather & 3.24 & 2.10 & 3.14 & 2.50 & 2.89 \\
\hline Manufacture of Wood, Products of Wood \& Furniture & 2.62 & 2.53 & 2.59 & 2.60 & 2.59 \\
\hline $\begin{array}{l}\text { Paper and Paper Products, Printing \& Reproduction of } \\
\text { Recorded Media }\end{array}$ & 3.02 & 2.55 & 2.82 & 2.95 & 2.87 \\
\hline Chemicals, Petroleum Products, Rubber and Plastic Products & 4.30 & 3.42 & 4.13 & 3.88 & 4.03 \\
\hline Non-metallic Mineral Products & 30.35 & 11.11 & 26.75 & 20.98 & 24.50 \\
\hline Basic Metals & 8.31 & 2.67 & 6.20 & 7.21 & 6.60 \\
\hline Fabricated Metal Products & 3.55 & 2.23 & 3.33 & 2.87 & 3.15 \\
\hline Other Manufacturing & 108.60 & 2.78 & 30.47 & 147.83 & 76.39 \\
\hline \multicolumn{6}{|c|}{ WORKING CAPITAL TURNOVER RATE (times) } \\
\hline Food, beverages and tobacco & 2.35 & 2.99 & 2.22 & 3.04 & 2.54 \\
\hline Textile, Wearing Apparel and Leather & 1.22 & 0.86 & 1.15 & 1.05 & 1.11 \\
\hline Manufacture of Wood, Products of Wood \& Furniture & 1.10 & 0.77 & 1.10 & 0.84 & 1.00 \\
\hline $\begin{array}{l}\text { Paper and Paper Products, Printing \& Reproduction of } \\
\text { Recorded Media }\end{array}$ & 1.59 & 1.37 & 1.50 & 1.57 & 1.52 \\
\hline Chemicals, Petroleum Products, Rubber and Plastic Products & 1.85 & 1.32 & 1.77 & 1.57 & 1.69 \\
\hline Non-metallic Mineral Products & 1.28 & 1.27 & 1.13 & 1.51 & 1.28 \\
\hline Basic Metals & 1.12 & 0.89 & 1.05 & 1.05 & 1.05 \\
\hline Fabricated Metal Products & 1.24 & 1.43 & 1.16 & 1.50 & 1.29 \\
\hline Other Manufacturing & 2.63 & 1.56 & 2.42 & 2.14 & 2.31 \\
\hline \multicolumn{6}{|c|}{ NET WORKING CAPITAL TURNOVER RATE (times) } \\
\hline Food, beverages and tobacco & -1.50 & 4.76 & -2.66 & 5.17 & 0.41 \\
\hline Textile, Wearing Apparel and Leather & 3.05 & 2.80 & 2.77 & 3.29 & 2.97 \\
\hline Manufacture of Wood, Products of Wood \& Furniture & 2.39 & 1.63 & 1.95 & 2.48 & 2.16 \\
\hline $\begin{array}{l}\text { Paper and Paper Products, Printing \& Reproduction of } \\
\text { Recorded Media }\end{array}$ & 2.09 & 0.98 & 2.04 & 1.29 & 1.75 \\
\hline Chemicals, Petroleum Products, Rubber and Plastic Products & -0.10 & 8.26 & -1.00 & 7.81 & 2.45 \\
\hline Non-metallic Mineral Products & 5.87 & -22.79 & 5.54 & -15.91 & -2.85 \\
\hline Basic Metals & 2.25 & 2.09 & 2.14 & 2.29 & 2.20 \\
\hline Fabricated Metal Products & 5.14 & 3.30 & 4.56 & 4.61 & 4.58 \\
\hline Other Manufacturing & 7.08 & 6.56 & 6.06 & 8.27 & 6.92 \\
\hline
\end{tabular}

Source: All the information in the table is based on the data downloaded from ISE web site.

Note: * - End of the second quarter; ${ }^{* \star}$ - From the beginning of the third quarter. 
TABLE 6. PAIRED SAMPLES T-TEST RESUltS

\begin{tabular}{|c|c|c|c|c|c|c|c|c|c|}
\hline & & \multicolumn{5}{|c|}{ Paired Differences } & \multirow[t]{3}{*}{ t } & \multirow[t]{3}{*}{ df } & \multirow{3}{*}{$\begin{array}{l}\text { Sig. (2- } \\
\text { tailed) }\end{array}$} \\
\hline & & \multirow[t]{2}{*}{ Mean } & \multirow[t]{2}{*}{$\begin{array}{c}\text { Std. } \\
\text { Deviation }\end{array}$} & \multirow[t]{2}{*}{$\begin{array}{l}\text { Std. Error } \\
\text { Mean }\end{array}$} & \multicolumn{2}{|c|}{$\begin{array}{l}95 \% \text { Confidence } \\
\text { Interval of the } \\
\text { Difference }\end{array}$} & & & \\
\hline & & & & & Lower & Upper & & & \\
\hline \multicolumn{10}{|c|}{ Paired Samples Test Results (I.Period - II.Period ) } \\
\hline Pair 1 & $\begin{array}{l}\text { Current Ratio (Before Crisis) - Current } \\
\text { Ratio (After Crisis) }\end{array}$ & -.01352 & .83427 & .12437 & -.26416 & .23712 & -.109 & 44 & .914 \\
\hline Pair 2 & $\begin{array}{l}\text { Liquidity Ratio (Before Crisis) - Liquidity } \\
\text { Ratio (After Crisis) }\end{array}$ & .00106 & .68274 & .10178 & -.20405 & 20618 & .010 & 44 & .992 \\
\hline Pair 3 & $\begin{array}{l}\text { Cash Ratio (Before Crisis) - Cash Ratio } \\
\text { (After Crisis) }\end{array}$ & .101567 & .747079 & .111368 & -.122880 & .326015 & .912 & 44 & .367 \\
\hline Pair 4 & $\begin{array}{l}\text { Inventory Ratio (Before Crisis) - Inventory } \\
\text { Ratio (After Crisis) }\end{array}$ & .02941 & .10302 & .01536 & -.00155 & .06036 & 1.915 & 44 & .062 \\
\hline Pair 5 & $\begin{array}{l}\text { S.T. Receivables Ratio (Before Crisis) - } \\
\text { S.T. Receivables Ratio (After Crisis) }\end{array}$ & -.00321 & .13105 & .01954 & -.04259 & .03616 & -.165 & 44 & .870 \\
\hline Pair 6 & $\begin{array}{l}\text { Current Assets Ratio (Before Crisis) - } \\
\text { Current Assets Ratio (After Crisis) }\end{array}$ & -.01634 & .09021 & .01345 & -.04344 & .01076 & -1.215 & 44 & .231 \\
\hline Pair 7 & $\begin{array}{l}\text { S.T.Liabilities Ratio } 1 \text { (Before Crisis) - } \\
\text { S.T.Liabilities Rate (After Crisis) }\end{array}$ & -.03196 & .13546 & .02019 & -.07266 & .00874 & -1.583 & 44 & .121 \\
\hline Pair 8 & $\begin{array}{l}\text { S.T.Liabilities Ratio } 2 \text { (Before Crisis) - } \\
\text { S.T.Liabilities Ratio } 2 \text { (After Crisis) }\end{array}$ & -.00473 & .11894 & 01773 & -.04046 & .03101 & -.267 & 44 & .791 \\
\hline Pair 9 & $\begin{array}{l}\text { S.T.Liabilities Ratio } 3 \text { (Before Crisis) - } \\
\text { S.T.Liabilities Ratio } 3 \text { (After Crisis) }\end{array}$ & -.10464 & .14996 & .02235 & -.14969 & -.05958 & -4.681 & 44 & .000 \\
\hline Pair 10 & $\begin{array}{l}\text { Inventory Turnover Ratio (Before Crisis) - } \\
\text { Inventory Turnover Ratio (After Crisis) }\end{array}$ & -1.64295 & 12.05646 & 1.79727 & -5.26511 & 1.97921 & -.914 & 44 & .366 \\
\hline Pair 11 & $\begin{array}{l}\text { Receivables Turn. Ratio (Before Crisis) - } \\
\text { Receivables Turn. Ratio (After Crisis) }\end{array}$ & 10.13658 & 49.03029 & 7.30900 & -4.59375 & 24.86690 & 1.387 & 44 & .172 \\
\hline Pair 12 & $\begin{array}{l}\text { Work. Cap. Turn. Ratio (Before Crisis) - } \\
\text { Work. Cap. Turn. Ratio (After Crisis) }\end{array}$ & .15494 & 1.12560 & .16779 & -.18323 & .49310 & .923 & 44 & .361 \\
\hline Pair 13 & $\begin{array}{l}\text { Net Work. Cap. Turn. Ratio (Before Crisis) - } \\
\text { Net Work. Cap. Turn. Ratio (After Crisis) }\end{array}$ & 1.55701 & 21.30566 & 3.17606 & -4.84392 & 7.95794 & .490 & 44 & .626 \\
\hline \multicolumn{10}{|c|}{ Paired Samples Results (III.Period - IV.Period) } \\
\hline Pair 1 & $\begin{array}{l}\text { Current Ratio (Before Crisis) - Current } \\
\text { Ratio (After Crisis) }\end{array}$ & -.06254 & .82495 & .12298 & -.31038 & .18530 & -.509 & 44 & .614 \\
\hline Pair 2 & $\begin{array}{l}\text { Liquidity Ratio (Before Crisis) - Liquidity } \\
\text { Ratio (After Crisis) }\end{array}$ & -.02000 & .65103 & .09705 & -.21559 & .17559 & -.206 & 44 & .838 \\
\hline Pair 3 & $\begin{array}{l}\text { Cash Ratio (Before Crisis) - Cash Ratio } \\
\text { (After Crisis) }\end{array}$ & .12772 & .83782 & .12489 & -.12399 & .37942 & 1.023 & 44 & .312 \\
\hline Pair 4 & $\begin{array}{l}\text { Inventory Ratio (Before Crisis) - Inventory } \\
\text { Ratio (After Crisis) }\end{array}$ & .01957 & .09054 & .01350 & -.00763 & .04677 & 1.450 & 44 & .154 \\
\hline Pair 5 & $\begin{array}{l}\text { S.T. Receivables Ratio (Before Crisis) - } \\
\text { S.T. Receivables Ratio (After Crisis) }\end{array}$ & -.00643 & .12621 & .01881 & -.04435 & .03149 & -.342 & 44 & .734 \\
\hline Pair 6 & $\begin{array}{l}\text { Current Assets Ratio (Before Crisis) - } \\
\text { Current Assets Ratio (After Crisis) }\end{array}$ & -.02230 & .09336 & .01392 & -.05034 & .00575 & -1.602 & 44 & .116 \\
\hline Pair 7 & $\begin{array}{l}\text { S.T.Liabilities Ratio } 1 \text { (Before Crisis) - } \\
\text { S.T.Liabilities Rate (After Crisis) }\end{array}$ & -.02135 & .14044 & .02094 & -.06354 & .02084 & -1.020 & 44 & .313 \\
\hline Pair 8 & $\begin{array}{l}\text { S.T.Liabilities Ratio } 2 \text { (Before Crisis) - } \\
\text { S.T.Liabilities Ratio } 2 \text { (After Crisis) }\end{array}$ & -.00403 & .12363 & .01843 & -.04118 & .03311 & -.219 & 44 & .828 \\
\hline Pair 9 & $\begin{array}{l}\text { S.T.Liabilities Ratio } 3 \text { (Before Crisis) - } \\
\text { S.T.Liabilities Ratio } 3 \text { (After Crisis) }\end{array}$ & -.08787 & .14567 & .02171 & -.13164 & -.04411 & -4.047 & 44 & .000 \\
\hline Pair 10 & $\begin{array}{l}\text { Inventory Turnover Ratio (Before Crisis) - } \\
\text { Inventory Turnover Ratio (After Crisis) }\end{array}$ & -2.04766 & 9.40632 & 1.40221 & -4.87363 & .77831 & -1.460 & 44 & .151 \\
\hline Pair 11 & $\begin{array}{l}\text { Receivables Turn. Ratio (Before Crisis) - } \\
\text { Receivables Turn. Ratio (After Crisis) }\end{array}$ & -7.57791 & 52.68473 & 7.85378 & -23.4062 & 8.25033 & -.965 & 44 & .340 \\
\hline Pair 12 & $\begin{array}{l}\text { Work. Cap. Turn. Ratio (Before Crisis) - } \\
\text { Work. Cap. Turn. Ratio (After Crisis) }\end{array}$ & -.13478 & .89501 & .13342 & -.40367 & .13411 & -1.010 & 44 & .318 \\
\hline Pair 13 & $\begin{array}{l}\text { Net Work. Cap. Turn. Ratio (Before Crisis) - } \\
\text { Net Work. Cap. Turn. Ratio (After Crisis) }\end{array}$ & -17989 & 17.77344 & 2.64951 & -5.51963 & 5.15984 & -.068 & 44 & .946 \\
\hline
\end{tabular}


Paired Samples Results (2007 4.Quarter - 2008 4.Quarter)

\begin{tabular}{|c|c|c|c|c|c|c|c|c|c|}
\hline \multicolumn{10}{|c|}{ Paired Samples Results (2007 4.Quarter - 2008 4.Quarter) } \\
\hline & & \multicolumn{5}{|c|}{ Paired Differences } & \multirow[t]{3}{*}{$\mathrm{t}$} & \multirow[t]{3}{*}{$\mathrm{df}$} & \multirow{3}{*}{$\begin{array}{l}\text { Sig. }(2 \\
\text { tailed })\end{array}$} \\
\hline & & \multirow[t]{2}{*}{ Mean } & \multirow[t]{2}{*}{$\begin{array}{c}\text { Std. } \\
\text { Deviation }\end{array}$} & \multirow[t]{2}{*}{$\begin{array}{l}\text { Std. Error } \\
\text { Mean }\end{array}$} & \multicolumn{2}{|c|}{$\begin{array}{l}95 \% \text { Confidence } \\
\text { Interval of the } \\
\text { Difference }\end{array}$} & & & \\
\hline & & & & & Lower & Upper & & & \\
\hline$\overline{\text { Pair } 1}$ & $\begin{array}{l}\text { Current Ratio (Before Crisis) - Current } \\
\text { Ratio (After Crisis) }\end{array}$ & .02724 & 1.05326 & .15701 & -.28919 & .34367 & .174 & 44 & .863 \\
\hline Pair 2 & $\begin{array}{l}\text { Liquidity Ratio (Before Crisis) - Liquidity } \\
\text { Ratio (After Crisis) }\end{array}$ & -.02227 & .89276 & .13308 & -.29048 & .24595 & -.167 & 44 & .868 \\
\hline Pair 3 & $\begin{array}{l}\text { Cash Ratio (Before Crisis) - Cash Ratio } \\
\text { (After Crisis) }\end{array}$ & -.12814 & .52694 & .07855 & -.28645 & .03017 & -1.631 & 44 & .110 \\
\hline Pair 4 & $\begin{array}{l}\text { Inventory Ratio (Before Crisis) - Inventory } \\
\text { Ratio (After Crisis) }\end{array}$ & .03830 & .11176 & .01666 & .00473 & .07188 & 2.299 & 44 & .026 \\
\hline$\overline{\text { Pair } 5}$ & $\begin{array}{l}\text { S.T. Receivables Ratio (Before Crisis) - } \\
\text { S.T. Receivables Ratio (After Crisis) }\end{array}$ & .02982 & .15763 & .02350 & -.01754 & .07718 & 1.269 & 44 & .211 \\
\hline Pair 6 & $\begin{array}{l}\text { Current Assets Ratio (Before Crisis) - } \\
\text { Current Assets Ratio (After Crisis) }\end{array}$ & .00761 & .13607 & .02028 & -.03327 & .04849 & .375 & 44 & .709 \\
\hline Pair 7 & $\begin{array}{l}\text { S.T.Liabilities Ratio } 1 \text { (Before Crisis) - } \\
\text { S.T.Liabilities Rate (After Crisis) }\end{array}$ & -.04330 & .10854 & .01618 & -.07591 & -.01069 & -2.676 & 44 & .010 \\
\hline Pair 8 & $\begin{array}{l}\text { S.T.Liabilities Ratio } 2 \text { (Before Crisis) - } \\
\text { S.T.Liabilities Ratio } 2 \text { (After Crisis) }\end{array}$ & .03363 & .31875 & .04752 & -.06213 & .12939 & .708 & 44 & .483 \\
\hline Pair 9 & $\begin{array}{l}\text { S.T.Liabilities Ratio } 3 \text { (Before Crisis) - } \\
\text { S.T.Liabilities Ratio } 3 \text { (After Crisis) }\end{array}$ & -.08787 & .18751 & .02795 & -.14420 & -.03153 & -3.143 & 44 & .003 \\
\hline Pair 10 & $\begin{array}{l}\text { Inventory Turnover Ratio (Before Crisis) - } \\
\text { Inventory Turnover Ratio (After Crisis) }\end{array}$ & -3.03448 & 21.44668 & 3.19708 & -9.47777 & 3.40882 & -.949 & 44 & .348 \\
\hline Pair 11 & $\begin{array}{l}\text { Receivables Turn. Ratio (Before Crisis) - } \\
\text { Receivables Turn. Ratio (After Crisis) }\end{array}$ & 56.05895 & 310.22585 & 46.24574 & -37.1432 & 149.26112 & 1.212 & 44 & .232 \\
\hline Pair12 & $\begin{array}{l}\text { Work. Cap. Turn. Ratio (Before Crisis) - } \\
\text { Work. Cap. Turn. Ratio (After Crisis) }\end{array}$ & .38033 & 1.14030 & .16999 & .03774 & .72291 & 2.237 & 44 & .030 \\
\hline Pair 13 & $\begin{array}{l}\text { Net Work. Cap. Turn. Ratio (Before Crisis) } \\
\text { Net Work. Cap. Tur Ratio (After Crisis) }\end{array}$ & 8.09760 & 34.69883 & 5.17260 & -2.32709 & 18.52228 & 1.565 & 44 & .125 \\
\hline
\end{tabular}


TABLE 7. MANN - WhitNEY U-TEST RESULTS

\begin{tabular}{lcccc}
\hline \multirow{2}{*}{ (I.Period - II.Period ) } & \multicolumn{4}{c}{ Test Statistics } \\
\cline { 2 - 5 } & $\begin{array}{c}\text { Mann- } \\
\text { Whitney U }\end{array}$ & Wilcoxon W & Z & $\begin{array}{c}\text { Significance } \\
\text { (2-tailed) }\end{array}$ \\
\hline Current Ratio & 883.000 & 1918.000 & -1.045 & 0.296 \\
\hline Liquidity Ratio & 910.000 & 1945.000 & -0.827 & 0.408 \\
\hline Cash Ratio & 952.000 & 1987.000 & -0.488 & 0.625 \\
\hline Inventory Ratio & 874.000 & 1909.000 & -1.118 & 0.264 \\
\hline S.T. Receivables Ratio & 1011.000 & 2046.000 & -0.012 & 0.990 \\
\hline Current Assets Ratio & 963.000 & 1998.000 & -0.399 & 0.690 \\
\hline S.T.Liabilities Ratio 1 & 890.000 & 1925.000 & -0.989 & 0.323 \\
\hline S.T.Liabilities Ratio 2 & 973.000 & 2008.000 & -0.319 & 0.750 \\
\hline S.T.Liabilities Ratio 3 & 715.000 & 1750.000 & -2.401 & 0.016 \\
\hline Inventory Turnover Ratio & 897.000 & 1932.000 & -0.932 & 0.351 \\
\hline Receivables Turn. Ratio & 656.000 & 1691.000 & -2.877 & 0.004 \\
\hline Work. Cap. Turn Ratio & 699.000 & 1734.000 & -2.530 & 0.011 \\
\hline Net Work. Cap. Tur Ratio & 865.000 & 1900.000 & -1.190 & 0.234 \\
\hline
\end{tabular}

(III.Period - IV.Period)

\begin{tabular}{lllll}
\hline Current Ratio & 917.000 & 1952.000 & -0.771 & 0.441 \\
\hline Liquidity Ratio & 944.000 & 1979.000 & -0.553 & 0.580 \\
\hline Cash Ratio & 982.000 & 2017.000 & -0.246 & 0.806 \\
\hline Inventory Ratio & 928.000 & 1963.000 & -0.682 & 0.495 \\
\hline S.T. Receivables Ratio & 985.000 & 2020.000 & -0.222 & 0.824 \\
\hline Current Assets Ratio & 953.000 & 1988.000 & -0.480 & 0.631 \\
\hline S.T.Liabilities Ratio 1 & 919.000 & 1954.000 & -0.755 & 0.451 \\
\hline S.T.Liabilities Ratio 2 & 974.000 & 2009.000 & -0.311 & 0.756 \\
\hline S.T.Liabilities Ratio 3 & 750.000 & 1785.000 & -2.118 & 0.034 \\
\hline Inventory Turnover Ratio & 973.000 & 2008.000 & -0.319 & 0.750 \\
\hline Receivables Turn. Ratio & 946.000 & 1981.000 & -0.537 & 0.592 \\
\hline Work. Cap. Turn Ratio & 977.000 & 2012.000 & -0.286 & 0.775 \\
\hline Net Work. Cap. Tur Ratio & 981.000 & 2016.000 & -0.254 & 0.799 \\
\hline
\end{tabular}

2007 Q4 - 2008 Q4

\begin{tabular}{lcccc}
\hline Current Ratio & 893.000 & 1928.000 & -0.964 & 0.335 \\
\hline Liquidity Ratio & 928.000 & 1963.000 & -0.682 & 0.495 \\
\hline Cash Ratio & 948.000 & 1983.000 & -0.520 & 0.603 \\
\hline Inventory Ratio & 822.000 & 1857.000 & -1.537 & 0.124 \\
\hline S.T. Receivables Ratio & 897.000 & 1932.000 & -0.932 & 0.351 \\
\hline Current Assets Ratio & 1005.000 & 2040.000 & -0.061 & 0.952 \\
\hline S.T.Liabilities Ratio 1 & 898.000 & 1933.000 & -0.924 & 0.355 \\
\hline S.T.Liabilities Ratio 2 & 1012.000 & 2047.000 & -0.004 & 0.997 \\
\hline S.T.Liabilities Ratio 3 & 804.000 & 1839.000 & -1.683 & 0.092 \\
\hline Inventory Turnover Ratio & 1006.000 & 2041.000 & -0.052 & 0.958 \\
\hline Receivables Turn. Ratio & 844.000 & 1879.000 & -1.360 & 0.174 \\
\hline Work. Cap. Turn Ratio & 877.000 & 1912.000 & -1.093 & 0.274 \\
\hline Net Work. Cap. Tur Ratio & 803.000 & 1838.000 & -1.691 & 0.091 \\
\hline
\end{tabular}

